\title{
The Usefulness of Interactive Governance for Underground Planning
}

\author{
Ehsan Nouzari, Thomas Hartmann, and Tejo Spit
}

\begin{abstract}
The underground provides many spatial planning opportunities as it offers space for structures, but also functions as a resource for energy. To guide developments and use the capabilities the underground provides, the Dutch national government started a policy process for the Structuurvisie Ondergrond (a master plan). Stakeholders are involved in the policy process because of the many interests linked to underground functions. However, past policy processes related to the underground dealt with lack of stakeholder satisfaction. This article explores a quantitative approach by focusing on (a) statistical testing of four criteria of interactive governance and (b) using said criteria to evaluate the satisfaction of stakeholders in a policy process. This article highlights the usefulness of a more quantitative approach and provides new insights into the relation between interactive governance and the procedural satisfaction of stakeholders. It also provides insights that help to improve interactive governance in terms of process management to achieve greater procedural satisfaction.
\end{abstract}

Keywords: communication, interactive governance, participation, procedural satisfaction, stakeholder involvement, underground planning

\section{Introduction}

Dissatisfaction toward traditional ways of dealing with societal complexity has led to the use of interactive governance as a method to govern society. Following the definition of Jacob Torfing and colleagues (2012: 2-3), interactive governance is "the complex process through which a plurality of social and political actors with diverging interests interact in order to formulate, promote, and achieve common objectives by means of mobilizing, exchanging, and deploying a range of ideas, rules, and resources." Within this spectrum different forms of interactive governance can be distinguished (Edelenbos and Meerkerk 2016; Torfing et al. 2012). A popular form of spatial policy making in Western countries is government-induced interactive governance (Edelenbos and Meerkerk 2016). With this form of interactive governance, governments often decide how, when, and which stakeholders are involved through 
participation procedures that are structured by rules. At certain points within the policy process, governments give stakeholders the ability to respond to plans and provide input on decision making (Edelenbos 2005; Edelenbos and Meerkerk 2016).

Within spatial policy making, this form of interactive governance is mainly used as an instrument to effectively and efficiently solve societal issues (Irvin and Stansbury 2004; Koppenjan and Klijn 2004; Sørensen and Torfing 2007). Government-induced interactive governance is used as an instrument for mediation between interdependent stakeholders, with each having their own interests and resources (Edelenbos and Meerkerk 2016). Within contemporary society, resources like knowledge, financial means, and support are scattered, resulting in complex interdependent relationships between stakeholders. It is argued that instrumental forms of interactive governance have the potential to effectively solve (wicked) societal problems by realigning dispersed resources through the involvement of government and nongovernment stakeholders (Koppenjan and Klijn 2004; Sørensen and Torfing 2007). It is also argued that this instrumental form has the potential to realize efficient implementation of policy by creating satisfaction and support, discouraging stakeholders from using their veto powers, and stopping implementation through legal action (Edelenbos and Klijn 2006; Irvin and Stansbury 2004; Kooiman 1993).

Scientific contributions often take the benefits of interactive governance as described above for granted. Some scholars, however, criticize this view as overly optimistic (lanniello et al. 2018; Mohan and Stokke 2000; Swyngedouw 2005). For example, the involvement of many stakeholders with different interests may lead to debates and conflicts, eventually stagnating with deadlocks and impasses (Koppenjan and Klijn 2004). It can also be time-consuming and therefore financially costly. Interactive governance does not automatically lead to success, as it requires extensive stakeholder and process management activities (Billé 2008; Edelenbos and Klijn 2006). From a more critical perspective, Mario lanniello and colleagues (2018) performed a systematic literature review to establish obstacles as described in the two examples above for successful stakeholder involvement and practical recommendations to address them. The analysis considered successful stakeholder involvement as any example where the authors reported an improved degree of engagement. They concluded that some benefits of interactive governance were found in their research; however, evidence of decision making becoming more efficient and effective is small. For further research on interactive governance, they recommended evaluation 
criteria and more standardized quantitative tools for data collection, as both are largely absent in contemporary literature, hindering systematic evaluation, comparison, and generalization of findings (Eisenhardt 1991; Hoon 2013; lanniello et al. 2018; Rowe et al. 2008).

This discourse on interactive governance inspired the twofold aim of this study. First, it focuses on constructing criteria based on interactive governance for the evaluation of one benefit described in the literature, namely, reaching satisfaction among stakeholders for the implementation of spatial policy. The criteria are based on the interactive governance definition of Jurian Edelenbos (2000: 39): "the early involvement of citizens and other stakeholders in policy making, in which on the basis of transparency, equality, and reasonable debate, solutions are explored that influence the final decision making" (translated from Dutch by the author).

Second, the evaluation criteria based on interactive governance is used to construct a standardized quantitative method to measure satisfaction among stakeholders in a policy process. The case chosen is the Dutch policy process of the Structuurvisie Ondergrond for underground spatial planning. The data from the measurement is used to establish if there is a correlation between the evaluation criteria and the satisfaction of stakeholders. The assumption that interactive governance makes is that the better the four criteria of interactive governance (equality, reasonable debate, transparency, and influence) are implemented into a stakeholder process, the higher the procedural satisfaction of stakeholders will be (satisfaction of stakeholders for the process they are involved in) (Edelenbos 2000; Graaf 2007). This leads to the following research question: Do the four criteria of interactive governance correlate positively with the procedural satisfaction of stakeholders in the policy process for the Structuurvisie Ondergrond?

\section{The Four Criteria of Interactive Governance}

The definition of interactive governance provided by Edelenbos (2000: 39) offers four criteria to capture the essence of the approach, namely, equality, influence, reasonable debate, and transparency. These criteria, however, are dated because of the progression made in governance literature over the course of the last decade. To update the four initial criteria outlined by Edelenbos, the governance literature was evaluated for approaches that mention specific criteria connected with interactive governance. To update the criteria, Graham Smith's (2009) democratic 
innovations literature was used because the four criteria he outlined strongly correlate with the four criteria outlined by Edelenbos (2000) in terms of theoretical background. The criteria were merged together to form the following four criteria.

Equality focuses on neutralizing inequalities between stakeholders in two aspects, namely, presence and voice. Presence is about equality in the access and involvement of stakeholders. To accomplish this, selection procedures need to be fair. Every (key) stakeholder in society needs to have the chance to participate regardless of interest, position, or background. If not, the assumption cannot be made that decisions include the concerns and interests of stakeholders. In short, it is about the fairness of the selection procedures and the level of access to the policy process. Voice is about equality in possibilities for stakeholders to be heard (for example, during meetings), which does not necessarily mean that they will contribute (Edelenbos 2000; Smith 2009). In this case, the input of one actor should not have more influence than the input of another. A difference in communication skills between stakeholders can create disparities. This means that achieving equality goes beyond giving opportunities to provide input. It is also accomplished through mitigation of differences in properties, resources, and skills of actors. It is necessary to mention that inequality between stakeholders always exists to some extent. A completely equal planning process does not exist, but the main goal should be to minimize inequalities as much as possible (Edelenbos 2000).

Influence relates to the ability of stakeholders to exert influence in a policy process. For stakeholders to have influence, their input needs to be given a place in policy and must be considered when making decisions. This can be achieved by giving stakeholders decision-making abilities or by using their input in policy documents and decisions. When determining influence, a distinction can be made between two moments in a policy process: the agenda-setting phase and the moment of definitive decision making. Within the agenda-setting phase, it is important for actors to have influence on the selection of issues, subjects, and problems that will be solved through the policy process (Edelenbos 2000; Smith 2009). In the moment of definitive decision making, it is crucial that the decision makers are bound to the outcome of the participatory process (Graaf 2007).

Reasonable debate refers to conversations where stakeholders try to convince each other by the (in)correctness of arguments. It is reason and fairness that determine the power of arguments rather than the stakeholders' resources, positions, and place in the hierarchy within the 
process. Decisions are made through careful consideration of arguments presented during the process (Edelenbos 2000). To make this possible, stakeholders need to be somewhat receptive. Receptivity is the appreciation and openness of stakeholders toward other participants' perspectives, perceptions, and experiences. Stakeholders can do this by letting go of their own views and using the views of others to broaden their own. The legitimacy of stakeholder involvement is dependent on actors' receptivity and their capacity to make reflective and considered judgments. The expectation is that choices are not limited solely to the interests and knowledge of particular stakeholders when they have a chance to influence policy. Stakeholder processes can stimulate the receptivity of stakeholders by using a wide variety of methods but can never guarantee their success in making everyone heard evenly (Smith 2009).

Transparency refers to the extent to which stakeholders share information and expectations in a planning process. First, transparency through accessibility of information, in terms of content as well as procedure, makes it easier for stakeholders to formulate problems and solutions (Edelenbos 2000). Furthermore, in a transparent process, stakeholders can make critical statements on different aspects of the process, which helps to determine the stakeholders' level of trust in the process and its legitimacy (Smith 2009). Second, expectations for the process from all participating parties must be clear so that all participants know how to contribute. This includes, for example, the influence stakeholders will have or the role they will fulfill in the policy process (Graaf 2007; Smith 2009). Management of expectations is especially important, because of the often diverging and rising expectations. When stakeholders are involved, they expect that their interests, ideas, and preferences will be taken into account. This is not always possible, resulting in expectations going unmet, leading to a low level of support for final decisions (Koppenjan and Klijn 2004; Marcussen and Torfing 2007; Teisman et al. 2001).

To conclude, equality, influence, reasonable debate, and transparency are the characteristics of an interactive stakeholder process. Interactive governance literature assumes that there is a positive correlation between how "interactive" a stakeholder process is and the procedural support among stakeholders (Edelenbos 2000; Graaf 2007). Procedural support is defined as follows: the satisfaction of stakeholders for the process they participate in (Graaf 2007). The four criteria of interactive governance provide the basis for more operationalized criteria to measure and evaluate the procedural satisfaction of stakeholders in a policy process. The data gathered from the measurements is used to determine 
if there is a statistical correlation between the evaluation criteria and the procedural satisfaction of stakeholders. The case in which procedural satisfaction is measured to establish a correlation is the policy process for the Structuurvisie Ondergrond. Details about this policy process and why it was chosen for the purpose of this research is outlined in the next paragraph.

\section{The Policy Process for the Structuurvisie Ondergrond and Past Mistakes}

Spatial development underground can be considered the final frontier because of the many possibilities it offers. It functions as a space in which structures can be built, such as the Madrid M30 motorway, which freed up space aboveground (Admiraal and Cornaro 2016; Cornaro and Admiraal 2012). The underground is also a resource that can facilitate the shift toward sustainability to combat climate change by generating heat, such as through geothermal energy (Bloomfield et al. 2003). However, making use of the space underground will require governments to overcome the "first come first served" mentality that has caused the underground to become a disorganized space with conflicting functions (Admiraal and Cornaro 2016; Brown 2011). To achieve sustainable use of the underground, a comprehensive policy framework needs to be made to determine a balance between use of or preservation of the underground (Admiraal and Cornaro 2016).

The Dutch national government recognizes the importance of such a policy framework to guide spatial developments in the underground. Through the Ministry of Infrastructure and Environment, a policy process was started in 2011 to make the Structuurvisie Ondergrond (Ministerie van Infrastructuur en Milieu 2016). A structuurvisie in the Netherlands is a policy document in which a framework outlines how to deal with certain spatial planning fields like the underground (Van Buuren et al. 2008; Van Buuren et al. 2010). The Dutch government established the policy framework for the underground through a stakeholder process in which citizens, companies, NGOs, knowledge institutions, interest groups, provinces, and municipalities were involved. Involvement took place through participation procedures like one-on-one meetings, citizen panels, executive meetings, and advisory boards, and through media outlets like newsletters. These participation procedures were used as a mediation tool to create satisfaction with the implementation (Ministerie van Infrastructuur en Milieu 2012). 
There are two reasons why a policy process for underground spatial planning was chosen. First, many interests are bound to underground spatial planning. The underground can be used for the extraction of resources like gas, minerals like sand and stone, energy like geothermal, and infrastructure like cables, pipelines, and roads. These interests are bound to different stakeholders because of the "first come first served" strategy, resulting in a suboptimal and nonsustainable use of the underground. To create a comprehensive policy framework for sustainable use of the underground, where use of and preservation of the space are in balance, these stakeholders need to be involved (Admiraal and Cornaro 2016).

Second, underground planning can be classified as a wicked problem. These are policy issues that are unstructured (no clear problem definition with little consensus on the solution), crosscutting (interconnected to other issues, policy domains, and levels of government), and relentless (never going to be solved once and also creating problems in other policy domains) (Rittel and Webber 1973; Weber and Khademian 2008). This is clearly illustrated in two failed policy processes of the past related to underground planning. Notable are the policy processes for carbon capture and storage (CCS) in the municipality of Barendrecht (2006-2010) and the extraction of shale gas in the municipalities of Boxtel and Haaren (2009-2015). Both processes were questioned by the stakeholders as regards the necessity of the initiative through their own perspectives, which were influenced by their beliefs, values, and presumptions.

In total, there were two conflicting perspectives on the initiatives. Companies (Shell and Cuadrilla) and the Dutch national government viewed the initiatives mainly from a techno-economical perspective. For both CSS and shale gas, the initiative was a safe climate mitigation measure in which earnings would also facilitate the shift toward more sustainable energy. Public stakeholders like citizens, NGOs, and municipalities viewed the initiatives from a local-societal perspective. Stakeholders questioned the initiative by stating that better climate mitigation measures were available. In some instances, stakeholders even stated that CCS and shale gas would have the opposite effect. Using CCS, for example, could increase the use of coal, making it difficult for renewable energy sources to compete with nonrenewable sources. Stakeholders also questioned the safety of both initiatives. Using the shale gas case, stakeholders referred to a scene in a documentary called Gasland, which was about the shale gas exploitation in the United States, in which an individual lit running water on fire with a lighter. 
Both processes ended up in a deadlock because stakeholders had little influence on decision making and were not involved early enough. The focus of the government on the policy and technological options instead of the concerns of stakeholders also contributed to the failure (Brunsting et al. 2011; Cuppen et al. 2019).

According to literature, policy processes for underground planning can benefit from using interactive governance. Government-induced interactive governance is a mediation tool to manage the diverse interests in society to reach consensus. It is also a tool to cope with the complexity of managing (spatial) wicked problems (Kooiman 1993; Koppenjan and Klijn 2004; Torfing et al. 2012). Both benefits make the policy process for the Structuurvisie Ondergrond a suitable case for this research.

\section{Methodology}

The research question is answered through three steps followed in chronological order:

(1) Conceptualizing evaluation criteria to measure procedural satisfaction based on interactive governance;

(2) Designing a standardized quantitative data collection method to measure procedural satisfaction;

(3) Determining a correlation between the criteria used and the procedural satisfaction of stakeholders within the case. This last step is translated into the research question: Do the four criteria of interactive governance correlate positively with the procedural satisfaction of stakeholders in the policy process for the Structurrvisie Ondergrond?

To elaborate how data was collected to answer the research question (step 3), this section explains the method used and choices made by following the first two steps outlined above.

\section{Conceptualizing Evaluation Criteria to Measure Procedural Satisfaction}

The four criteria of interactive governance were conceptualized into specific process management criteria for the purpose of measuring procedural satisfaction and determining their correlation. Measuring procedural satisfaction through process management is fitting, as 
Table 1 - Conceptualized Criteria Organized by Corresponding Criteria of Interactive Governance

\begin{tabular}{|c|c|}
\hline $\begin{array}{l}\text { Criteria of Interactive } \\
\text { Governance }\end{array}$ & Conceptualized Evaluation Criteria \\
\hline 1. Equality & $\begin{array}{l}\text { - The number of opportunities available to provide } \\
\text { input during meetings. } \\
\text { - Equal opportunities to provide input. } \\
\text { - The number of meetings. } \\
\text { - Facilitation and stimulation of stakeholders to } \\
\text { provide input (during meetings). }\end{array}$ \\
\hline 2. Influence & $\begin{array}{l}\text { - Providing input early in the process (i.e., problem } \\
\text { definition phase). } \\
\text { - Opportunities through stakeholder procedures to } \\
\text { provide input. } \\
\text { - Opportunities to provide problem definitions. } \\
\text { - } \text { Taking interests, expectations, concerns, arguments, } \\
\text { ideas, perspectives, and ways of thinking seriously. } \\
\text { - Processing provided input in policy and decisions. }\end{array}$ \\
\hline 3. Reasonable debate & $\begin{array}{l}\text { - Discussing ideas and arguments during meetings. } \\
\text { - Focusing on substance of issues and policy } \\
\text { problems during meetings. }\end{array}$ \\
\hline 4. Transparency & $\begin{array}{ll}\text { - } & \text { Receiving and discussing concept (policy) } \\
& \text { documents. } \\
- & \text { Receiving information in understandable language. } \\
- & \text { Receiving information about what has been done } \\
& \text { with the provided input. } \\
- & \text { Discussing interests, expectations, concerns, and } \\
& \text { responsibilities. } \\
- & \text { Receiving information about the input of } \\
& \text { stakeholders in other parts of the process. }\end{array}$ \\
\hline
\end{tabular}

Table 1 shows the conceptualized evaluation criteria corresponding to the four criteria of interactive governance. To get a better understanding of how satisfaction is measured, the conceptualization of the four criteria of interactive governance into the evaluation criteria is explained.

government-induced policy processes (such as the case of this research) use interactive governance as a mediation tool to create satisfaction among stakeholders (instrumental). It is this process of mediation that stakeholders can be questioned about to convey their satisfaction.

\section{Survey to Collect Data for Multiple Regressions}

The empirical analysis was based on data collected through an online survey. The survey is meant to measure the procedural satisfaction of 
stakeholders on each of the evaluation criteria discussed in the previous paragraph. In the survey, stakeholders were asked to give a grade (1 to 10) for each of the evaluation criteria-which referred to specific parts of a policy process in which stakeholders are involved-based on the four criteria of interactive governance (Table 1) to measure the satisfaction of stakeholders. Stakeholders were also asked to give a final grade for how satisfied they were about the involvement process as a whole. To provide stakeholders a clear line between satisfied and dissatisfied, the cutoff point was set at 5.5.

The numerical data gathered through the measurement was used to determine a correlation between the evaluation criteria and the procedural satisfaction of stakeholders. The assumption according to interactive governance was that dissatisfied stakeholders will give low grades and satisfied stakeholders will assign high grades. A regression analysis determined if there was a positive significant correlation between the evaluation criteria (independent $X$ variables: grade criteria) and the procedural satisfaction of stakeholders (dependent $Y$ variable: final grade).

\section{Response and Nonresponse}

The survey was distributed to all 168 stakeholders who participated in the different forums of the policy process for the Structuurvisie Ondergrond. The population consists of citizens, companies, provinces, municipalities, government agencies, NGOs, and other ministries of the Dutch national government. The team within the Dutch Ministry of Infrastructure and Environment that is responsible for the policy process had the e-mail addresses of all stakeholders. The head of the policy process sent the survey to all stakeholders with a description of the research, an explanation regarding the anonymity of survey responses, and the contact information of the researcher for further questions. The population had one month, from 1 June to 1 July of 2015, to fill in the survey. In total, 94 participants completed the questionnaire (57.32 percent), which means a nonresponse rate of 74 (42.68 percent). Two completed questionnaires were removed to protect the validity of the data, because the answers to all questions on these two surveys were identical. 


\section{Correlations Between the Criteria of Interactive Governance}

Before moving on to the regression analysis to establish if there was a correlation between the criteria and the procedural satisfaction of stakeholders, a factor analysis was conducted. The reasoning for the factor analysis was the expected theoretical correlation between the criteria of interactive governance. For example, within government-induced interactive governance, the government decides when and how stakeholders are involved. Stakeholders do not have any chances to have reasonable debates when meetings are only meant to inform them, which also results in stakeholders lacking influence.

Table 2 - Description of the Factors and the Indicators (survey questions)

\begin{tabular}{|c|c|}
\hline Factors & Indicators \\
\hline $\begin{array}{l}\text { 1. Discussing the interests, expectations, } \\
\text { concerns, arguments, ways of thinking, } \\
\text { and incentives of stakeholders and taking } \\
\text { them seriously. }\end{array}$ & 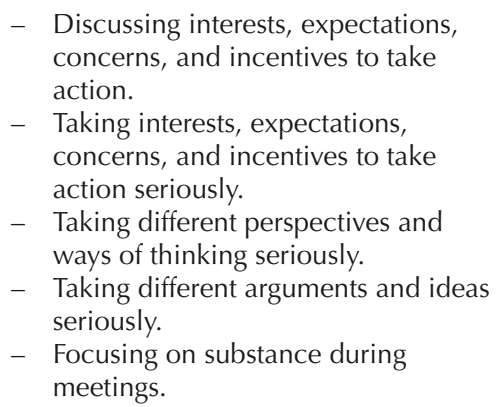 \\
\hline $\begin{array}{l}\text { 2. Sufficient chances within the process } \\
\text { to provide input in early stages (i.e., } \\
\text { problem definition phase). }\end{array}$ & $\begin{array}{l}\text { - Processing provided input in policy } \\
\text { and decisions. } \\
\text { - Providing input early in the process } \\
\text { (i.e., problem definition phase). }\end{array}$ \\
\hline $\begin{array}{l}\text { 3. Stimulating and facilitating stakeholders } \\
\text { to provide input and receiving } \\
\text { information about the input of other } \\
\text { stakeholders. }\end{array}$ & $\begin{array}{l}\text { - Facilitation and stimulation of } \\
\text { participants to provide input. } \\
\text { - Receiving information about the } \\
\text { input of participants in other parts of } \\
\text { the process. }\end{array}$ \\
\hline $\begin{array}{l}\text { 4. Receiving information (in understandable } \\
\text { language) and discussing concept } \\
\text { documents. }\end{array}$ & $\begin{array}{ll}- & \text { Receiving and discussing concept } \\
\text { (policy) documents. } \\
-\quad \text { Receiving information in } \\
\text { understandable language. }\end{array}$ \\
\hline 5. Ability to provide input during meetings. & $\begin{array}{l}\text { - The number of situations available to } \\
\text { provide input. } \\
\text { - } \quad \text { Equal opportunities to provide input. }\end{array}$ \\
\hline 6. The number of meetings to provide input. & - The number of meetings. \\
\hline
\end{tabular}


The factor analysis resulted in six factors even though the literature of interactive governance distinguishes four criteria (Table 2). The first explanation for this outcome and the reason for some factors corresponding to more than one criteria of interactive governance is the theoretical correlations between the criteria (as described above). The second explanation is the broadness of the four criteria of interactive governance. The criterion transparency, for example, refers to the clarity of expectations and information (documents, decisions, and other parts of the process) alike. In short, the factor analysis took the criterion transparency and split it into two separate criteria (factors 1 and 4 in Table 2). The following six factors were derived from the factor analysis:

- Factor 1, discussing interests, expectations, concerns, arguments, ways of thinking, and incentives of stakeholders and taking them seriously corresponds with the criteria transparency, influence, and reasonable debate. Managing expectations through discussing expectations and concerns (transparency), giving arguments and brainstorming ideas (reasonable debate), and having them taken seriously (influence) are aspects that correlate highly. When sharing expectations and concerns, for example, stakeholders also want their expectations and concerns to be taken seriously.

- Factor 2, sufficient chances to provide input early in the process corresponds with the criterion influence. To have influence on policy, stakeholders need to be able to provide input in the early stages when problems are still being defined and their input needs to be processed in decisions being made.

- Factor 3, facilitating stakeholders to provide input and receiving information about the input of other stakeholders corresponds with the criteria equality and transparency. Some stakeholders lack communicative skill to convey their concerns and interests compared to others in the same process. Facilitating those stakeholders makes it possible to take into account the interests and concerns of stakeholders that are not gifted communicators.

- Factor 4, receiving information (for example, concept policy documents) in understandable language corresponds with the criteria of transparency. Transparency is not only about sharing information, but also about how understandable it is to the public.

- Factors 5 and 6 are related to the criterion equality. Providing enough opportunities (number of meetings, but also chances during meetings) is important to avoid disparities in opportunities stakeholders have to let their voices be heard. 


\section{Correlations Between the Criteria and the Procedural Satisfaction of Stakeholders}

Scientific literature about interactive governance assumes that adopting it results in procedural satisfaction among stakeholders. If this assumption is valid, interactive governance can be used to evaluate and improve participatory policy processes. The assumption was tested statistically through a multiple regression analysis by using the data collected in the first part of the survey.

First, we have to establish if there is a correlation between the factors and the procedural satisfaction of stakeholders (Table 3). The Pearson correlation coefficients show a significant correlation for the first four factors with a degree of reliability at 99 percent (sig. < 0.01) and for the last two with a degree of reliability at 95 percent (sig. $<0.05$ ). Second, we have to establish if the beta coefficient is positive and significantly different than zero. If so, our factors of interactive governance (independent variables $X$ ) significantly predict the procedural satisfaction of stakeholders (dependent variable $Y$ ). For the Structuurvisie Ondergrond, each factor significantly predicts the procedural satisfaction with a degree of reliability of 99 percent (sig. < 0.01).

The results of the analysis show that there is a significant positive correlation between the factors and the procedural satisfaction of the stakeholder in the policy process for the Structuurvisie Ondergrond. However, the strength of the correlation for each factor varies when examining the Pearson coefficient (Table 3). Factor 1, which is about being treated seriously and about management of expectations and interests (criteria: influence and transparency), has the strongest correlation with the procedural satisfaction of stakeholders. This suggests that

Table 3 - Results of Multiple Regression Analysis

\begin{tabular}{|l|c|c|c|c|c|}
\hline & B & Beta & Sig. & Pearson & Sig. \\
\hline (Constant) & 6.924 & & 0.000 & & \\
\hline Factor 1 & 0.762 & 0.618 & 0.000 & 0.618 & 0.000 \\
\hline Factor 2 & 0.392 & 0.318 & 0.000 & 0.318 & 0.001 \\
\hline Factor 3 & 0.499 & 0.404 & 0.000 & 0.404 & 0.000 \\
\hline Factor 4 & 0.425 & 0.345 & 0.000 & 0.345 & 0.000 \\
\hline Factor 5 & 0.228 & 0.185 & 0.000 & 0.185 & 0.039 \\
\hline Factor 6 & 0.238 & 0.193 & 0.000 & 0.193 & 0.033 \\
\hline
\end{tabular}


stakeholders that participate in a policy process have certain interests they want to accomplish. This does not mean stakeholders expect all their input to be implemented, but it does mean that stakeholders want to be taken seriously. In short, interests need to be discussed, input needs to be implemented where possible, and if not, feedback is necessary on why certain input was not taken into account in the policy process. The correlation for factors $2-4$ is moderately strong. Factors 5 and 6 are weakly correlated. These factors are about equal opportunities to provide input and equal treatment between stakeholders (criterion: equality). Stakeholders conveyed in the survey that equality is important but that total equality is unreachable. Differences in communication skills and the power stakeholders hold simply due to their position in a hierarchy are impossible to neutralize. Stakeholders do find it important that everyone has the ability to provide input and is being heard but accept that true equality is impossible.

To determine the extent to which the procedural satisfaction of stakeholders is explained through the criteria of interactive governance, the $R$-squared is observed. Knowing the extent determines the usefulness of interactive governance for planning practitioners to achieve satisfaction among stakeholders. If the explained variance is relatively low, then most of the satisfaction of stakeholders is determined through other factors unrelated to interactive governance. Knowing the extent also determines the usefulness of interactive governance as an analytical tool to evaluate planning processes in which stakeholders are involved. Examining the $R$-squared reveals that 83.6 percent of the procedural satisfaction is explained by the criteria of interactive governance. This means that, for the policy process for the Structuurvisie Ondergrond, 16.4 percent of the satisfaction of stakeholders is explained through factors unrelated to interactive governance.

\section{Procedural Satisfaction for the Stakeholder Process of the Structuurvisie Ondergrond}

Within the policy process for the Structuurvisie Ondergrond, interactive governance plays a significant positive role in determining the procedural satisfaction of stakeholders. This means that improvements based on interactive governance will actually increase the degree of procedural satisfaction. To illustrate how the methodology of this research can serve to evaluate and improve stakeholder processes, the results for the policy process for the Structuurvisie Ondergrond are outlined. 
Table 4 a Procedural Satisfaction of Stakeholders for the Policy Process of the Structuurvisie Ondergrond

\begin{tabular}{|l|c|}
\hline Indicators for Interactive Governance & Average \\
\hline Discussing concerns & 6.95 \\
\hline Taking concerns seriously & 6.94 \\
\hline Discussing interests & 6.95 \\
\hline Taking interests seriously & 6.94 \\
\hline Discussing expectations & 6.91 \\
\hline Taking expectations seriously & 6.91 \\
\hline Discussing responsibilities & 6.81 \\
\hline Taking responsibilities seriously & 7.09 \\
\hline Focusing on substance & 7.21 \\
\hline Taking different perspectives seriously & 7.15 \\
\hline Taking ideas and arguments seriously & 7.03 \\
\hline Providing problem definitions & 7.46 \\
\hline Providing problem definitions early & 7.36 \\
\hline Allowing process input in documents & 6.88 \\
\hline Number of meetings & 6.85 \\
\hline Opportunities for stakeholders to provide input & 7.58 \\
\hline Equal opportunities to provide input & 7.47 \\
\hline Stimulating stakeholders to provide input & 7.21 \\
\hline Information provided in understandable language & 7.25 \\
\hline Information about provided input & 6.37 \\
\hline Information about input provided by others & 6.31 \\
\hline Discussing concept documents & 6.86 \\
\hline Final grade & 6.97 \\
\hline
\end{tabular}

The first part of the survey determines the satisfaction of stakeholders relating to different parts of a process based on interactive governance. By asking stakeholders to assign a grade for each aspect of the process, one can gain an overall sense of the degree of participants' satisfaction. This provides insight into which parts of the process need attention. Stakeholders gave the policy process for the Structuurvisie Ondergrond an average final grade of 6.97 out of 10 (Table 4). The average grades for each of the different aspects of interactive governance diverge from the average final grade with a deviation of approximately 0.5. At first glance, a legitimate conclusion based on the final grade would be that 
stakeholders are satisfied with the process. It would also be legitimate to conclude that a relatively small number of aspects of the process need attention and improvement based on the low deviation from the final grade. But this interpretation bears a problem. The difference between a six and a seven, for example, does not mean that the stakeholder who gave the lower score is less satisfied, because she or he may interpret the grades with a more critical lens. Also, when a participant grades the process with an eight or higher, she or he can still think the process should be improved. Stakeholders may hold the process to different standards. Measuring only the stakeholders' satisfaction in the form of grades, therefore, is not enough. Determining which improvements stakeholders would like to see gives meaning and body to the grades. To illustrate this premise, the results of the second part of the survey are examined.

To determine if stakeholders' grades translate to their level of satisfaction, the percentage of stakeholders who think the process needs

Table 5 - Most Desirable Improvements as Suggested by Stakeholders

\begin{tabular}{|c|c|c|}
\hline Criteria & $\%$ & Most Desirable Improvements \\
\hline $\begin{array}{l}\text { Transparency } \\
\text { (information) }\end{array}$ & $\begin{array}{l}78.3 \\
49.0 \\
37.0 \\
32.0\end{array}$ & $\begin{array}{l}\text { Stakeholders who think the process needs to improve in } \\
\text { this aspect. } \\
-\quad \text { Receiving a mail or newsletter periodically. } \\
-\quad \text { Gaining access to documents so the development of the } \\
\text { policy process can be closely followed. } \\
-\quad \text { Receiving information about the input other participants } \\
\text { provided. }\end{array}$ \\
\hline $\begin{array}{l}\text { Transparency } \\
\text { (expectations) }\end{array}$ & $\begin{array}{l}72.8 \\
38.0 \\
34.8 \\
33.7 \\
25.0\end{array}$ & $\begin{array}{l}\text { Stakeholders who think the process needs to improve in } \\
\text { this aspect. } \\
-\quad \text { Discussing each other's interests more often. } \\
-\quad \text { Discussing each other's incentives to take action more } \\
\text { often. } \\
-\quad \text { Discussing each other's concerns more often. } \\
-\quad \text { Discussing each other's responsibilities more often. }\end{array}$ \\
\hline Influence & $\begin{array}{l}72.8 \\
26.1 \\
21.7\end{array}$ & $\begin{array}{l}\text { Stakeholders who think the process needs to improve in } \\
\text { this aspect. } \\
-\quad \text { Reaching requirements in the policy and the process. } \\
- \text { Getting invited to other meetings in the process. }\end{array}$ \\
\hline $\begin{array}{l}\text { Reasonable } \\
\text { debate }\end{array}$ & $\begin{array}{l}\mathbf{6 3 . 0} \\
22.8 \\
22.8 \\
33.7\end{array}$ & $\begin{array}{l}\text { Stakeholders who think the process needs to improve in } \\
\text { this aspect. } \\
-\quad \text { Being better informed about documents and decisions. } \\
-\quad \text { Making different views visible. } \\
-\quad \text { Searching for similarities during discussions and debates. }\end{array}$ \\
\hline Equality & $\begin{array}{l}38.0 \\
15.2\end{array}$ & $\begin{array}{l}\text { Stakeholders who think the process needs to improve in } \\
\text { this aspect. } \\
\text { - Being offered more opportunities and time for discussion } \\
\text { and conversation. }\end{array}$ \\
\hline
\end{tabular}


to be improved is examined. Even though the policy process for the Structuurvisie Ondergrond received an average final grade of 6.97 out of 10, a relatively high percentage of stakeholders think that the process needs to be improved (Table 5). The percentages range from 63 to 78 percent, with the exception of the criterion equality. It is possible that equality is not viewed as important for stakeholders' satisfaction as the other criteria. The criterion equality shows the weakest correlation compared to the other criteria of interactive governance (Table 4). This means that equality influences stakeholders' satisfaction level the least. It is also possible that stakeholders are mostly satisfied with the equality of opportunities and the treatment they receive.

Most stakeholders think the process can be improved upon in terms of influence, reasonable debate, and transparency. However, this result does not provide any concrete ideas for the actual improvement efforts. Quantitative research is suitable for determining how most stakeholders think the process could be improved because it is easier to reach a large number of stakeholders in the process. When stakeholders' suggestions for improvements of the policy process for the Structuurvisie Ondergrond are combined with the results of the statistical analysis, we can proceed to determine if an improvement will actually lead to a rise in satisfaction levels. The statistical analysis has demonstrated that the criteria of interactive governance play a positive role in the procedural satisfaction of stakeholders.

\section{Conclusion}

This article explored the statistical relationship between interactive governance and the procedural satisfaction of stakeholders involved in a policy process. It tested the assumption that there is a positive correlation between the criteria of interactive governance and the procedural satisfaction of stakeholders in a process. To test the assumption, four criteria of interactive governance were formulated, namely, equality, influence, reasonable debate, and transparency, and these were used as independent variables.

This article provided new quantitative insights into the relation between interactive governance and the procedural satisfaction of stakeholders in a process. It can be concluded that the four criteria of interactive governance play a statistically positive role in the procedural satisfaction of stakeholders in the policy process for the Structuurvisie Ondergrond. The criteria and methods used to test 
the assumption highlight the usefulness of interactive governance in different ways.

This research has shown how the criteria of interactive governance can be used as an analytical tool for quantitative research and compliment qualitative findings. As mentioned above, most research on governance uses a qualitative case study design. Using quantitative statistical research, however, provides a new perspective on the usefulness of governance approaches. Laurens de Graaf (2007), for example, tested the assumption that interactive governance leads to procedural support among stakeholders through qualitative case study research. But the research did not provide insight into, for example, the extent to which each aspect of interactive governance plays a role in stakeholders' satisfaction. The quantitative statistical approach introduced in this article tested the same assumption but unveiled new insights. These new insights further help us to understand how and to what extent interactive governance plays a role in procedural support among stakeholders.

This research has also shown that the criteria of interactive governance are highly suitable for quantitative methods for comparative and longitudinal research. The survey method constructed from the criteria is easily replicable for data collection and has highly standardized procedures for analysis (factor and regression analyses). Such methods help in tackling the lack of external validity of interactive governance literature through finding general patterns.

The method introduced in this article is not only useful for scientific data collection but also for planning practitioners. The criteria of interactive governance can be used to measure the procedural satisfaction of stakeholders in policy processes. The results can be used to determine how much the criteria correlate with their satisfaction through a regression analysis. This gives planners insight into how effective their process design and management are in achieving consensus and support among stakeholders. It also gives insight into which aspects of the process need improvement to reach (higher) procedural satisfaction.

The criteria used to measure satisfaction are also useful for process management to avoid mistakes made in past policy processes for underground planning. Past processes for CCS and shale gas in the Netherlands failed because stakeholders were not involved early enough and lacked influence in the decision making. Another reason for the failure was that the government did not take the perspectives of local stakeholders seriously or address concerns. Mistakes like these can be avoided through process management guidelines. Such guidelines are necessary because interactive governance does not automatically lead to 
successful implementation of policy. Process management is necessary to make use of the potential benefits interactive governance provides, such as consensus for implementation and managing wicked problems.

The results outlined in this article raise new research questions. First, this article shows a positive correlation between interactive governance and the satisfaction of stakeholders in a policy process related to underground planning. Whether the same correlation can be found in stakeholder processes unrelated to policy and the underground is still unclear. To obtain a better understanding of the role of interactive governance in the satisfaction of stakeholders, further (quantitative) research needs to be conducted. Second, the four criteria play a role in the procedural satisfaction of stakeholders in the policy process for the Structuurvisie Ondergrond by 83.6 percent. This means that 16.4 percent of the satisfaction of stakeholders is explained through other factors. This percentage may differ across different stakeholder processes, but it still means that the four criteria of interactive governance are not all-encompassing. Research needs to be conducted to determine what other criteria play a role in the procedural satisfaction of stakeholders. Third, this article focuses on procedural satisfaction and not content satisfaction. Even though the four criteria of interactive governance may also correlate positively with the content satisfaction of stakeholders, this was not tested in this article. Further (quantitative) research needs to be conducted to gain more insight into this matter.

Ehsan Nouzari is currently conducting his $\mathrm{PhD}$ research on the subject of interactive governance and is affiliated with Utrecht University. Ehsan Nouzari has a background in spatial planning and works as a process manager for infrastructure and flood risk management projects.

E-mail: ehsannouzari@hotmail.com

Thomas Hartmann is Associate Professor at the Landscape and Spatial Planning Group of Wageningen University. He is also affiliated with the Czech Jan Evangelista Purkyne University (UJEP) in Usti nad Labem, Faculty of Social and Economic Studies. Thomas Hartmann has a spatial planning background, and he addresses environmental issues with a sociopolitical perspective.

E-mail: thomas.hartmann@wur.nl

Tejo Spit is Professor in Urban and Regional Planning at the Department of Human Geography and Planning of Utrecht University. Tejo Spit specializes in land policy, planning methodology, infrastructure planning, and administrative aspects of spatial planning. E-mail: t.j.m.spit@uu.nl 


\section{References}

Admiraal, Han, and Antonia Cornaro. 2016. "Why Underground Space Should be Included in Urban Planning Policy-And How This Will Enhance an Urban Underground Future." Tunneling and Underground Space Technology 55: 241-220.

Billé, Raphael. 2008. "Integrated Coastal Zone Management: Four Entrenched Illusions." Surveys and Perspectives Integrating Environment and Society 1 (2): 75-86.

Bloomfield, K. Kit, Joseph N. Moore, and Robert M. Neilson. 2003. "Geothermal Energy Reduces Greenhouse Gases." Geothermal Resources Council 32 (2): 77-79.

Brown, Hillary. 2011. "Eco-logical Principles for Next-Generation Infrastructure." The Bridge 41 (1): 19-26.

Brunsting, Suzanne, Marjolein de Best-Waldhober, Christina F. J. Feenstra, and Tom Mikunda. 2011. "Stakeholder Participation Practices and Onshore CCS: Lessons from the Dutch Case Barendrecht." Energy Procedia 4: 6376-6383.

Buuren, Petrus J. J. van, Toon A. A. J. de Gier, Tonny A. G. A. Nijmeijer, and Jan Robbe. 2008. Van WRO naar Wro. The Hague: IBR instituut voor bouwrecht.

Buuren, Petrus J. J. van, Toon A. A. J. de Gier, Tonny A. G. A. Nijmeijer, and Jan Robbe. 2010. Hoofdlijnen ruimtelijke bestuursrecht. Deventer: Kluwer.

Cornaro, Antonia, and Han Admiraal. 2012. "Changing World-Major Challenges: The Need for Underground Space Planning." In Proceedings 48th ISOCARP Congress, Perm. International Society of City and Regional Planners, The Hague.

Cuppen, Eefje, Udo Pesch, Sanne Remmerswaal, and Mattijs Taanman. 2019. "Normative Diversity, Conflict and Transition: Shale Gas in the Netherlands." Technological Forecasting \& Social Change. doi.org/10.1016/j.techfore.2016.11.004.

Edelenbos, Jurian. 2000. Proces in vorm: Procesbegeleiding van interactieve beleidsvorming over lokale ruimtelijke projecten. Utrecht: Uitgeverij Lemma BV.

Edelenbos, Jurian. 2005. "Institutional Implications of Interactive Governance: Insights from Dutch Practice." Governance: An International Journal of Policy, Administration and Institutions 18 (1): 111-134.

Edelenbos, Jurian, and Erik-Hans Klijn. 2006. "Managing Stakeholder Involvement in Decision Making: A Comparative Analysis of Six Interactive Processes on the Netherlands." Journal of Public Administration Research and Theory 16: 417-446.

Edelenbos, Jurian, and Ingmar van Meerkerk. 2016. Critical Reflections on Interactive Governance: Self-Organization and Participation in Public Governance. Cheltenham, UK: Edward Elgar Publishing.

Eisenhardt, M. Kathleen. 1991. "Better Stories and Better Constructs: The Case for Rigor and Comparative Logic." Academy of Management Review 16 (3): 620-627.

Graaf, Laurens de. 2007. Gedragen beleid: Een bestuurskundig onderzoek naar interactief beleid en draagvlak in de stad Utrecht. Delft: Eburon.

Hoon, Christina. 2013. "Meta-Synthesis of Qualitative Case Studies: An Approach to Theory Building." Organizational Research Methods 16 (4): 522-556.

lanniello, Mario, Silvia lacuzzi, Paolo Fedele, and Luca Brusati. 2018. "Obstacles and Solutions on the Ladder of Citizen Participation: A Systematic Review." Public Management Review 21 (1): 21-46.

Irvin, Renée A., and John Stansbury. 2004. "Citizen Participation in Decision Making: Is It Worth the Effort?" Public Administration Review 64 (1): 55-65.

Kooiman, Jan. 1993. Modern Governance: New Government-Society Interactions. London: Sage. 
Koppenjan, Joop, and Erik-Hans Klijn. 2004. Managing Uncertainties in Networks. London: Routledge.

Marcussen, Martin, and Jacob Torfing. 2007. Democratic Network Governance in Europe. Cheltenham, UK: Edward Elgar.

Ministerie van Infrastructuur en Milieu. 2012. Communicatie- en participatieplan Structuurvisie Ondergrond. The Hague: Ministerie van Infrastructuur en Milieu.

Ministerie van Infrastructuur en Milieu. 2016. Ontwerp Structuurvisie Ondergrond. The Hague: Ministerie van Infrastructuur en Milieu.

Mohan, Giles, and Kristian Stokke. 2000. "Participatory Development and Empowerment: The Dangers of Localism." Third World Quarterly 21 (2): 247-268.

Rittel, W. J. Horst, and Melvin M. Webber. 1973. "Dilemmas in General Theory of Planning." Policy Sciences 4: 155-169.

Rowe, Gene, Tom Horlick-Jones, John Walls, Wouter Poortinga, and Nick F. Pidgeon. 2008. "Analysis of a Normative Framework for Evaluating Public Engagement Exercises: Reliability, Validity and Limitations." Public Understanding of Science 17: 419-441.

Smith, Graham. 2009. Democratic Innovations: Designing Institutions for Citizen Participation. Cambridge: Cambridge University Press.

Sørensen, Eva, and Jacob Torfing. 2007. Theories of Democratic Network Governance. Camberley, UK: Edward Elgar Publishing.

Swyngedouw, Erik. 2005. "Governance Innovation and the Citizen: The Janus Face of Governance-Beyond-The-State." Urban Studies 42 (11): 1991-2006.

Teisman, Geert, Jurian Edelenbos, Erik-Hans Klijn, and Jeroen Verbart. 2001. "Ruimtelijke ontwikkelingsprocessen." In Besluitvorming en ruimtelijke procesmanagement: Studie naar eigenschappen van ruimtelijke besluitvorming die realisatie van meervoudig ruimtegebruik remmen of bevorderen, ed. Geert Teisman. 1-72. Delft: Eburon.

Torfing, Jacob, B. Guy Peters, Jon Pierre, and Eva Sorensen. 2012. Interactive Governance: Advancing the Paradigm. Oxford: Oxford University Press.

Weber, P. Edward, and Anne M. Khademian. 2008. "Wicked Problems, Knowledge Challenges, and Collaborative Capacity Builders in Network Settings." Public Administration Review 68 (2): 334-349. 